\title{
Individual biosafety barrier in dentistry: an alternative in times of covid-19. Preliminary study
}

\author{
Barreira individual de biossegurança odontológica: uma \\ alternativa em tempos de covid-19. Estudo preliminar
}

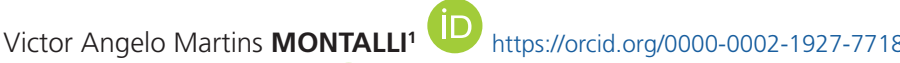

Aguinaldo Silva GARCEZ1 ${ }^{\text {ID }}$ https://orcid.org/0000-0003-2037-7211

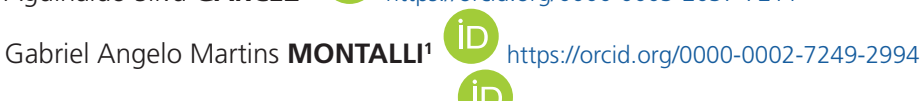

Fabiana Mantovani Gomes FRANÇA ${ }^{1}$ iD https://orcid.org/0000-0002-2877-6797

Selly Sayuri SUZUKI ${ }^{1}$ iD https://orcid.org/0000-0001-7493-746X

Letícia Marques Tondini MIAN² iD https://orcid.org/0000-0002-8783-7799

Rogério Heládio Lopes MOTTA ${ }^{1}$ iD https://orcid.org/0000-0002-6983-7883

Marcelo Henrique NAPIMOGA ${ }^{1}$ iD https://orcid.org/0000-0003-4472-365X

José Luiz Cintra JUNQUEIRA1 ID https://orcid.org/0000-0001-6788-4021
\end{abstract}

\section{ABSTRACT}

The return to dental practice in pandemic times is a new challenge due to the generation and dispersion of droplets and aerosols that may contain the SARS-CoV-2 virus, the etiological agent of covid-19. In the last months some droplet and aerosol containment strategies have been circulating on the internet, however, until now there is no evidence in the literature to prove the effectiveness of such barriers. Thus, using a microbial dispersion model with the fast handpiece, the aim of this preliminary study was to compare the dispersion caused by the the dental drill (DD) alone or in association with an individual biosafety barrier (IDBD / DD), which consisted of a layer of PVC film combined to a layer of polypropylene mounted on a frame. The dental drill was activated for one minute having had the water from the reservoir been replaced with a suspension of Lactobacillus casei Shirota. Petri dishes containing MRS agar were positioned at 50, 100 and $150 \mathrm{~cm}$ from the headboard of the dental chair at different angles (90 and 0 degrees). At $50 \mathrm{~cm}$, the mean (standard deviation) of $L$. casei Shirota for DD was 13,554.59 (493.48) CFU, while for IDBD / DD was 570.67 (60.54) CFU (p <0.0001), establishing a $96 \%$ reduction. Considering these preliminary results, the individual biosafety barrier proved effective in reducing dispersion from the dental drill in this study model, which suggests that this barrier may be a viable option to optimize biosafety in the dental environment.

Indexing terms: Indexing terms: Coronavirus infections. Containment of Biohazards. Dentistry. SARS-CoV-2.

$\boldsymbol{\nabla} \boldsymbol{\nabla} \boldsymbol{\nabla} \boldsymbol{\nabla}$

1 Faculdade São Leopoldo Mandic, Instituto de Pesquisas São Leopoldo Mandic, Laboratório de Microbiologia. Rua José Rocha Junqueira, 13, Swift, 13045-755, Campinas, SP, Brasil. Correspondence to: VAM MONTALLI. E-mail: <victor.montalli@slmandic.edu.br>.

2 Prefeitura Municipal de Monte Alto. Monte Alto, SP, Brasil.

$\boldsymbol{\nabla} \boldsymbol{\nabla} \boldsymbol{\nabla} \nabla$

How to cite this article

Montalli VAM, Garcez AS, Montalli GAM, França FMG, Suzuki SS, Mian LMT, et al. Individual biosafety barrier in dentistry: an alternative in times of Covid-19: preliminary study. RGO, Rev Gaúch Odontol. 2020;68:e20200018. http://dx.doi.org/10.1590/1981-863720200001820200088 


\section{RESUMO}

A retomada às atividades odontológicas em tempos de pandemia tem sido um desafio devido à geração e dispersão de gotículas e aerossóis que podem conter o vírus SARS-CoV-2, agente etiológico da covid-19. Nos últimos meses algumas estratégias de contenção de gotículas e aerossóis tem circulado pela internet, mas a eficácia destas barreiras ainda não apresenta um bom nível de evidência na Literatura. Desta forma, e utilizando um modelo de dispersão microbiana, o objetivo deste estudo preliminar foi comparar a dispersão da alta rotação $(A R)$ sem ou associada a uma barreira individual de biossegurança odontológica (AR / BIBO) que consiste em um bastidor acoplado ao filme de PVC e TNT. A turbina da alta rotação foi ativada durante um minuto em uma solução de Lactobacillus casei Shirota, a qual havia sido previamente acrescentada no reservatório de refrigeração de um equipamento odontológico, e placas de petri contendo ágar MRS foram posicionadas a partir do apoio de cabeça de uma cadeira odontológica nas distâncias de 50, 100 e $150 \mathrm{~cm}$ em diferentes ângulos (90 e 0 graus). Na distância de $50 \mathrm{~cm}$, a média (desvio padrão) de L. casei Shirota para AR foi de $13.554,59(493,48)$ UFC, enquanto a associação AR/BIBO foi de 570,67 $(60,54)$ UFC, estabelecendo uma redução de 96\% $(p<0,0001)$. Considerando estes resultados preliminares e o modelo de estudo utilizado, a barreira individual de biossegurança odontológica se mostrou eficiente em reduzir a dispersão da turbina de alta rotação, o que sugere que o seu uso pode ser uma alternativa para a melhoria da biossegurança em ambiente odontológico.

Termos de indexação: Infecções por Coronavirus. Contenção de riscos biológicos. Odontologia. Betacoronavirus.

\section{INTRODUCTION}

An outbreak of atypical pneumonia was reported in late December 2019 in Wuhan, China. A new human coronavirus ( $\mathrm{HCOV}$ ) was isolated in these cases and identified as a betacoronavirus and provisionally named a new 2019 corona virus (2019-nCoV). On February 11, 2020, the International Virus Taxonomy Committee named the virus "severe acute respiratory syndrome coronavirus 2" (SARSCoV2) and the World Health Organization announced the disease coronavirus 2019 (COVID-19) [1]. Based on the Pandemic Severity Assessment Framework (PSAF), it was observed that the disease had high transmissibility and clinical severity [2].

In times of covid-19 pandemic, among the many risks that dental professionals and their patients are exposed to, is the cross-infection by infected droplets and aerosols within the clinical environment, including that caused by the SARS-CoV-2 virus, which is why several countries and their dental associations have recommended or even forced dentists to postpone elective procedures and their professional activities were restricted to emergencies only [3]. Although symptomatic COVID-19 patients a regarded as the main source of transmission, some studies suggest that asymptomatic individuals and those in incubation period could be potential sources of contamination $[4,5]$, which makes the need for new biosafety strategies urgent for preventative purposes in the dental environment [6].

Unlike other health professionals, dentists work very close to the mouth of patients and, though the problem of cross-contamination has always existed, at the present time professionals are more aware and willing to follow new strategies to minimize risks to themselves, auxiliary staff, as well as patients $[7,8]$.

The current pandemic has raised awareness among health communities of the danger of occupational transmission of the virus and this has caused a shift to capricious care towards biosafety measures and the subject has become one of the main concerns for medical and dental practitioners $[2,3]$. Even so, cross-infection remains a risk for professionals and patients $[6,8]$ and probably occurs more frequently than the literature reports, partly due to the long incubation period of the disease and also to the large number and variety of extra office contacts $[6,9]$.

The use of a fast handpiece (dental drill), ultrasonic baths and air / water syringes cause the formation of droplets and aerosols $[8,9]$. Aerosol means any volume of air containing suspended solid or liquid particles. These particles can remain in suspension for a short or long period of time depending on their weight and size, which can vary between 0.001 and 10,000 $\mu \mathrm{m}$. Aerosol particles with diameters greater than $100 \mu \mathrm{m}$ are called droplets and, due to the gravitational force, settle more quickly than smaller particles [10]. Pathogenic microorganisms that may be present in saliva or blood can be transported by aerosol and contaminate people who are not adequately dressed in the clinical environment $[6,8,11]$.

The average air contamination increases more than three times during dental procedures when compared to the period prior to the start of treatment [12]. Particles suspended in the air during and after dental care can reach the respiratory tract and connective membranes of the dental professionals and the patients who will be treated subsequently $[11,13]$. 
Despite awareness of biohazards during procedures, mainly dispersion of aerosols that may contain pathogenic microorganisms, very few methods in the literature address strategies for containing aerosol generated by the dental drill. Also regarding a dental environment featuring several chairs (teaching environment), aerosol control barriers could be the means to resume dental teaching activities. Therefore, the objective of this preliminary study was to compare the dispersion caused by the use of a dental drill (DD) with or without an individual dental biosafety barrier (IDBD / DD) based on a microbial dispersion model.

\section{METHODS}

Droplet / aerosol dispersion study model in the dental environment using Lactobacillus casei Shirota and fluorescence:

The bacterial strain used was Lactobacillus casei Shirota present in the milk drink Yakult ${ }^{\circledR}$ (Lot: 1347-0). This strain was chosen because it is a bacterial species that poses no risk to humans in a clinical setting. A beverage package $(78 \mathrm{ml})$ was diluted in a saline solution $(390 \mathrm{ml})$, thus obtaining a final concentration of $1.5 \times 10^{8} \mathrm{CFU} / \mathrm{ml}$.

Microbiological tests for microbial growth were performed using agar selective for Lactobacillus spp. (Lactobacilli MRS Agar, Neogen, Lot: 109503B). After the collect, the samples were incubated in an oven at $37^{\circ} \mathrm{C}$ for 48 hours in aerobiosis.

Each postgraduate dental clinic has 12 dental equipment (Dabi Atlante ${ }^{\circledR}$ ) positioned at a distance of $2.0 \mathrm{~m}$ from each other. In the water container to be used to cool the dental drill, the solution prepared in the laboratory was placed in a concentration of $1.50 \times 108 \mathrm{CFU} / \mathrm{mL}$ of Lactobacillus casei Shirota.

Petri dishes with MRS agar were positioned from the headboard of the equipment, at distances of 50, 100 and $150 \mathrm{~cm}$, at 90 and 0 degree angles. The dental drill (Model 605C - Kavo ${ }^{\circledR}$ ) with a diamond tip attached (\# 2130, $\mathrm{FG}^{\circledR}$ ) was activated on a screen simulating cavity preparation for one minute. The plates were kept opened for 15 minutes. The doors and windows were kept closed during the procedures in order to avoid drafts (figure 1).

\section{Individual dental biosafety barrier}

This droplet and aerosol protection barrier is made using a $25 \mathrm{~cm}$ plastic frame (hoop used for embroidery) wrapped in PVC film and non-woven sheets (polypropylene, $40 \mathrm{~g} / \mathrm{cm}^{2}$, measuring $1.5 \times 1.5 \mathrm{~m}$ ), set up around the dental drill activation region (figure 2 ). The tests described above were repeated three times on different days, both
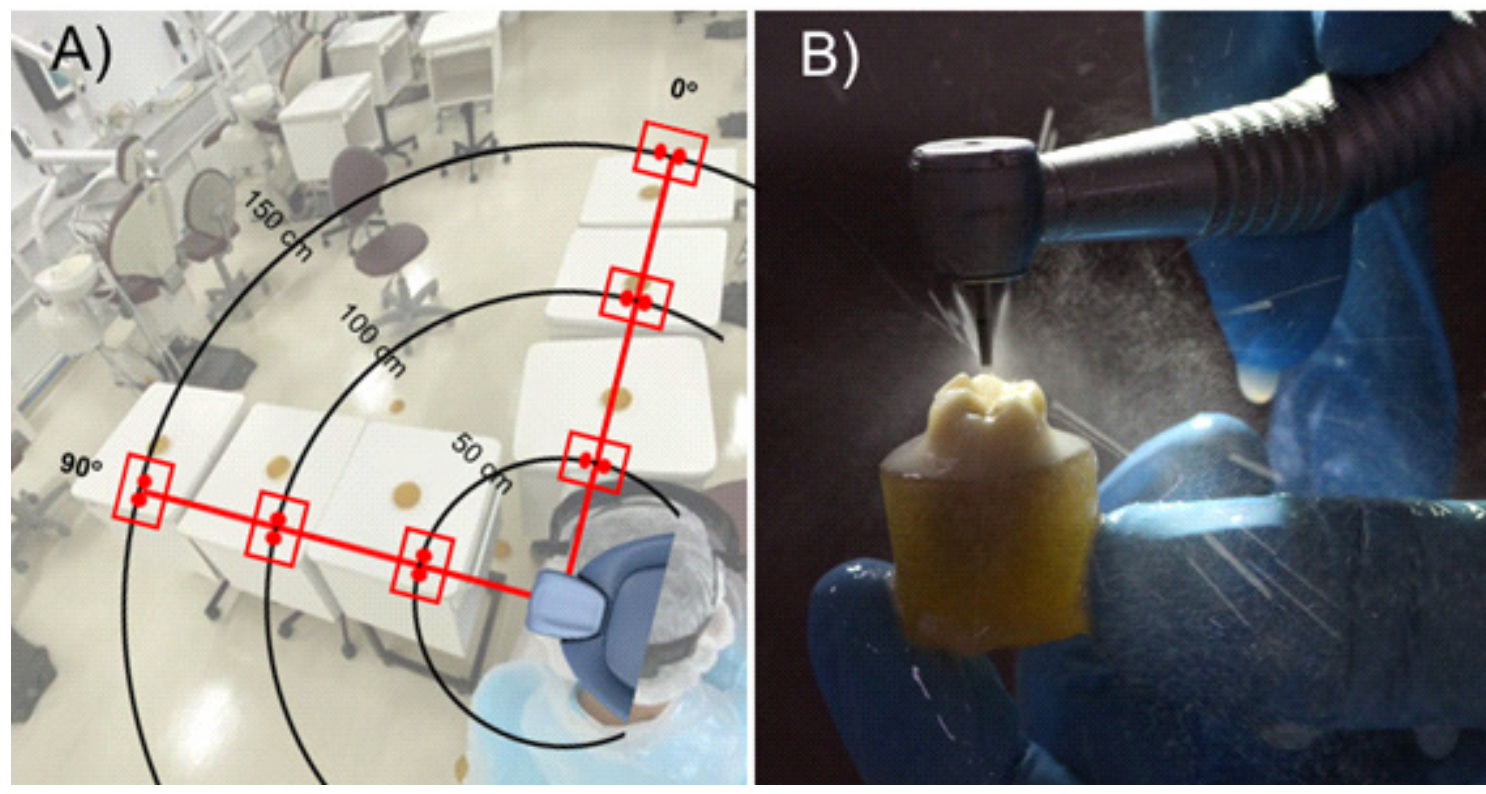

Figure 1. A) Distribution of the petri dishes in relation to the head of the dental chair. B) Detail of the DD generating droplets and aerossol. 

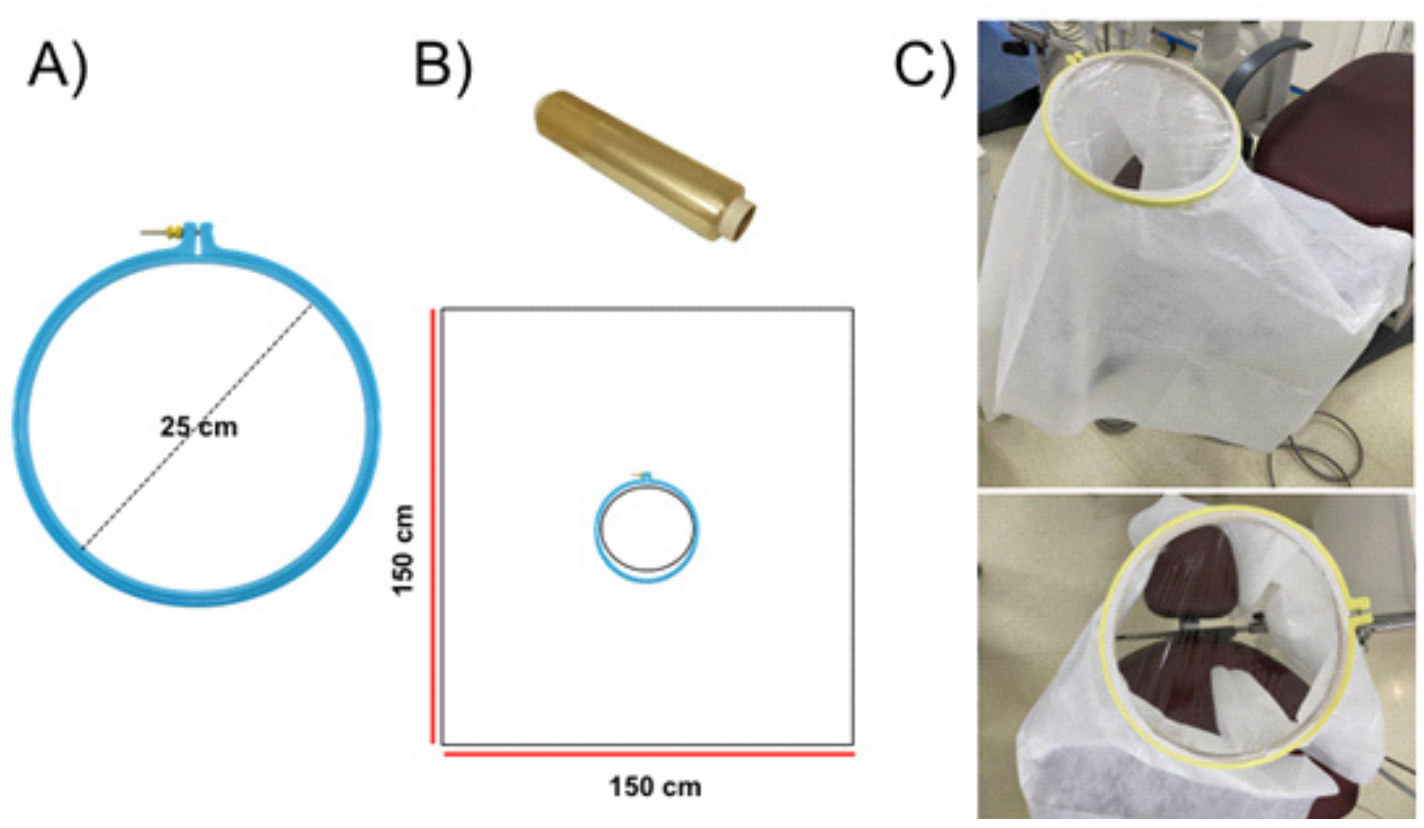

Figure 2. Individual biosafety barrier: A) $25 \mathrm{~cm}$ diameter frame; B) PVC film "sun roof" and polypropylene skirting (40 g/cm2, measuring $1.5 \times 1.5 \mathrm{~m}) \mathrm{mounted}$ on a circular frame; C) Individual Dental Barrier.

for dental drill alone and the dental drill with the barrier. The plates were placed in the an bacteriological incubator at $37^{\circ} \mathrm{C}$ and after 48 hours the CFUs were counted and compared.

\section{Fluorescence}

For the fluorescence test, $5 \mathrm{~mL}$ of $25 \%$ sodium fluorescein (Allergan, lot F56634, Guarulhos, SP, Brazil) was diluted in $800 \mathrm{~mL}$ of water with a final concentration of $3 \%$. The fluorescein solution was placed in the cooling tank of the dental equipment and the dental drill was used for 1 minute, as previously described. Images were obtained using a Canon camera (Model EOS Rebel SL1) and a $100 \mathrm{~mm}$ lens system associated with an optical diagnostic equipment that uses a light emitting diode (LED) as the excitation source, which emits the wave length of $405 \mathrm{~nm}$ and a bandpass filter with 470nm cut (Qscanplus, AIO BIO, South Korea).

\section{Statistical analysis}

Data from both experiments were examined for normality by the Shapiro-Wilk test. As data demonstrated normality, all analyzes were then performed using parametric methods. The differences in CFU for the different distances were compared by One-Way ANOVA, followed by Tukey's test. The level of significance was established at 5\%. All statistical analyzes were performed with GraphPad Prism v6.0.

\section{RESULTS}

The results of dental drill (DD) at $90^{\circ}$ and $0^{\circ}$ angles show a high count in comparison with the individual dental biosafety barrier (IDBD / DD) (table 1). At $50 \mathrm{~cm}$, the standard deviation (SD) of CFU of Lactobacillus casei Shirota for DD was 13554.59 (493.48) CFU, while for IDBD / DD was 570.67 (60.54) CFU ( $p<0.0001)$. At $100 \mathrm{~cm}$, the mean DD was 7761.64 (1005.26) CFU and IDBD / DD was 440.00 (95.37) CFU ( $p<0.0001)$. The mean (SD) in the distance of $150 \mathrm{~cm}$ for DD was 4464.00 (464.37) CFU, while for IDBD / DD was 226.00 (5.65) CFU ( $p<0.0001$ ) (figure 3). The average reduction between DD and IDBD / DD was $94.28 \%$.

With the turbine dispersion test using fluorescence, it was possible to notice droplets and aerosols spread both on the operator and in the clinical environment. On the other hand, the dental biosafety barrier was able to retain the droplets, agglutinated in the polypropylene, within the isolated field, reducing the dispersion of the aerosol significantly in the environment and the fluorescence from the lab coat on the operator (figure 4). 
Table 1. UFC in agar MRS within the clinical environment comparing the DD alone and the DD surrounded by the IDBD.

\begin{tabular}{|c|c|c|c|c|c|c|c|}
\hline & \multicolumn{3}{|c|}{ Dental drill } & \multicolumn{3}{|c|}{ Individual dental biosafety barrier / Dental drill } & $\%$ reduction \\
\hline \multicolumn{8}{|l|}{$90^{\circ}$} \\
\hline $50 \mathrm{~cm}$ & 13756.06 & 3722.08 & 3 & 553.33 & 171.69 & 3 & 95.98 \\
\hline $100 \mathrm{~cm}$ & 6779.06 & 1362.90 & 3 & 376.00 & 79.90 & 3 & 94.45 \\
\hline $150 \mathrm{~cm}$ & 3605.13 & 1340.72 & 3 & 274.00 & 14.00 & 3 & 92.40 \\
\hline $50 \mathrm{~cm}$ & 13353.13 & 4419.97 & 3 & 588.00 & 86.07 & 3 & 95.98 \\
\hline $100 \mathrm{~cm}$ & 8744.22 & 2784.57 & 3 & 504.00 & 214.77 & 3 & 94.45 \\
\hline $150 \mathrm{~cm}$ & 5322.87 & 682.58 & 3 & 178.00 & 22.00 & 3 & 92.40 \\
\hline
\end{tabular}

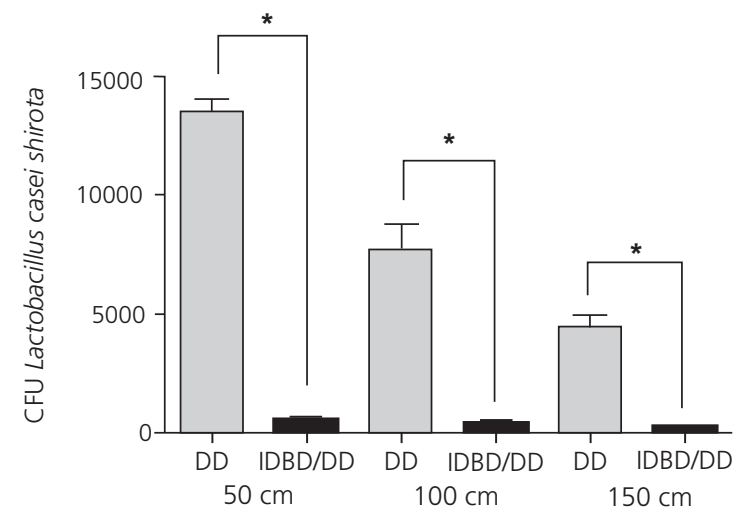

Figure 3. Mean (SD) Lactobacillus casei Shirota (CFU) between the dental drill alone (DD) and DD contained within the biosafety barrier (IDBD/DD). Legend: ${ }^{*}=p<0.0001$; one-way ANOVA and Tukey tests.
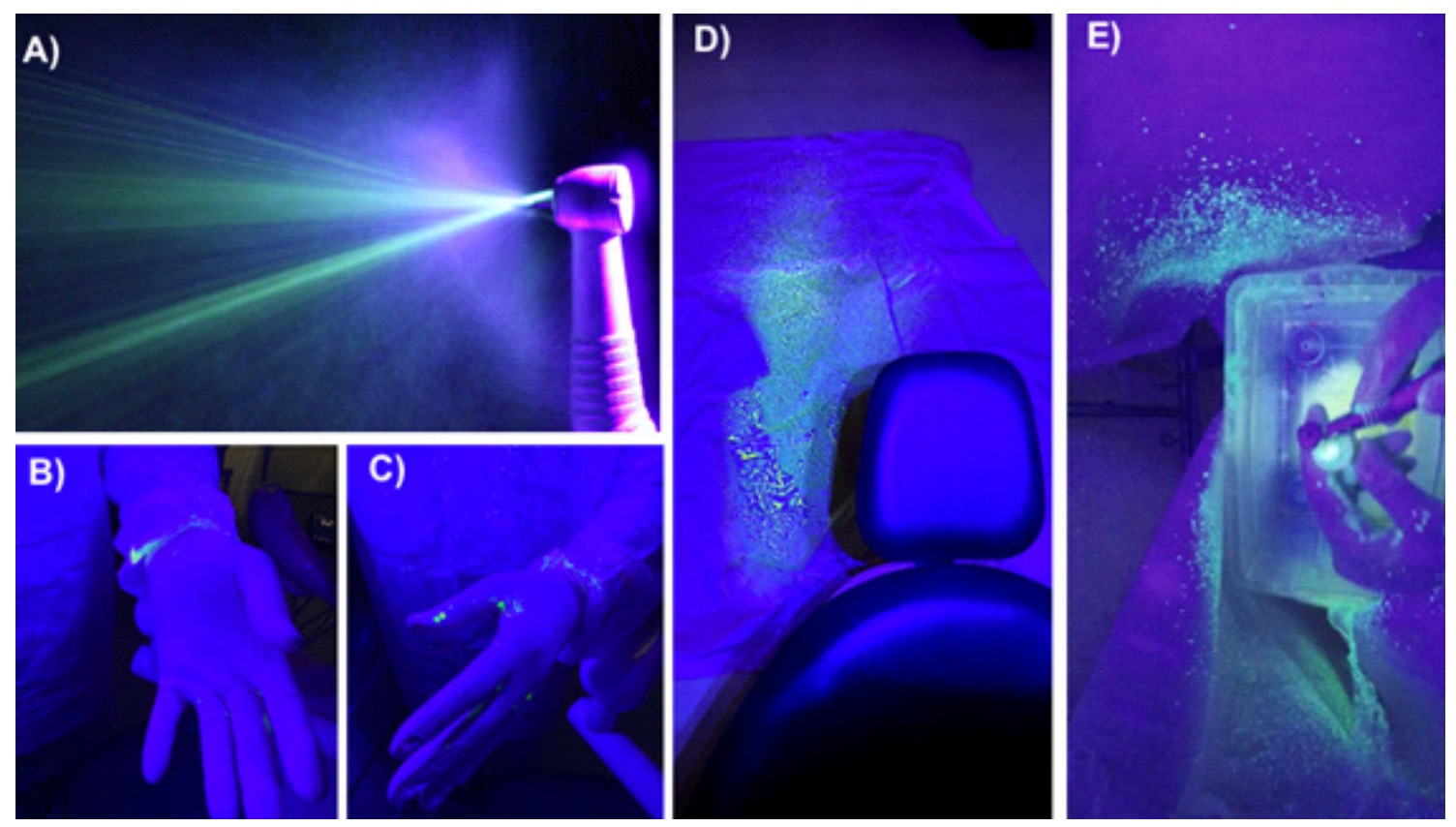

Figure 4. Fluorescence: A) Dental drill spraying droplets and aerosols; B \& C) Droplets on sleeves and gloves worn by the operator; D) droplets (green) within the clinical environment; E) Individual Dental Barrier retaining droplets and aerosols from the dental drill. 


\section{DISCUSSION}

Any particle present in aerosols, whatever size, may contain pathogenic microorganisms and cause crossinfection $[11,14]$. Therefore, it was possible to verify how microparticles disperse using collection and culture of microorganisms, based on a safe model of Lactobacillus casei Shirota suspension, as well as to suggest strategies for dental care with individual biosafety barriers $[6,8,13]$.

In dental procedures, the dental drill and water spray syringe generate droplets and aerosols that disperse in all directions over a distance of more than $2.0 \mathrm{~m}$ measured from the oral cavity perimeter [12], which was corroborated by the results of this study.

During a dental procedure, either in a single office or in collective care clinics, the neighboring benches and chairs as well as their respective patients, operators and sterilized instruments are commonly located within the dispersion area of droplets and aerosols. Therefore, there is a high risk of cross-contamination when carrying out such dental procedures $[6,15,16]$.

The literature is scarce on this subject, but some studies have reported that droplets are deposited on the operator, especially on their face $[14,17]$. In times of covid-19, this reinforces the need for personal protective equipment, especially protective eyewear, respirator (N95 or FFP2) and face shield, to prevent contamination possible traumatic injuries caused by fragments of restorations, active tips or broken drill bits $[6,8,11]$. This also reinforces the need to implement mandatory universal precautionary measures with effective infection control. The use of antimicrobial solutions are indicated to reduce the microbial load, as well as its spread $[18,19]$.

Furthermore, special attention should be given to the fact that contamination is cumulative along the workday and the measure adopted by the Brazilian Health Surveillance Agency, which recommends $1.5 \mathrm{~m}$ of minimum distance between the equipment dental care, may not prevent contamination by the SARS-CoV-2 virus. Due to air contamination exceeding the limits accepted by the ADA ( $\leq 200 \mathrm{CFU} \mathrm{/} \mathrm{mL),} \mathrm{many} \mathrm{studies} \mathrm{suggest}$ adopting additional measures such as the use of ultraviolet light after each procedure and the use of air conditioning with a HEPA filter and, whenever possible, attendance at individualized offices [20].
As an alternative measure, this preliminary study was designed to assess the efficacy of an individual dental biosafety barrier, which was able to reduce contamination by more than $90 \%$ over the different distances tested. The results presented herein are preliminary and, therefore, new strategies and adaptations can and should be implemented. However, the noticeable microbial reduction using a rack mounted with polypropylene and PVC film, which must be discarded after each use, allows any dentist to adapt it to their office. Therefore, we hope to help dental professionals to resume their clinical routine safely, in combination with the measures already recommended by international and national biosafety authorities, which must be maintained and strictly followed, including the updates that are constantly being produced during the pandemic.

It is interesting to note that a large concentration of droplets was found in the distal aspect of the lab coat sleeve, which reinforces the need for long-sleeved waterproof lab coats (polypropylene at $40 \mathrm{~g} / \mathrm{cm}^{2}$ ). Respecting the limitations of the present study, the results found herein point to the individual dental biosafety barrier as a viable option to enhance safety for the entire dental the team and their patients.

\section{CONCLUSION}

Considering the preliminary results and the experimental model presented herein, the individual dental biosafety barrier proved effective in reducing dispersion from the dental drill, making this device viable to enhance biosafety within the dental environment.

\section{Acknowledgements}

The authors acknowledge the invaluable technical assistance of Thiago Almeida and Gilca Saba in the laboratory of microbiology at Faculdade São Leopoldo Mandic, without whom this study would not have been possible. The authors should also acknowledge Dr. Marcelo Sperandio for promptly volunteering to review this manuscript regarding its English language content.

Conselho Nacional de Desenvolvimento Científico e Tecnológico (CNPq) (Research Productivity Fellowships were awarded to MHN and FMGF), Coordenação de Aperfeiçoamento de Pessoal de Nível Superior, CAPES (\#001). 


\section{Collaborators}

VAM MONTALLI, AS GARCEZ, GAM MONTALLI, FMG FRANÇA, SS SUZUKI, LMT MIAN, RHL MOTTA, MH NAPIMOGA and JLC JUNQUEIRA, conceptualization, data curation, formal analysis, funding acquisition, investigation, methodology, project administration, resources, software, supervision, validation, visualization, writing-original draft and writing-review \& editing.

\section{REFERENCES}

1. Wu Y, Ho W, Huang $Y$, Jin D-Y, Li S, Liu S-H, et al. SARS-CoV-2 is an appropriate name for the new coronavirus. Lancet. 2020;395(10228):949-950. http://dx.doi.org/10.1016/S014 0-67 36(20)30557-2

2. Napimoga $M H$, Freitas ARR. Dentistry vs Severe Acute Respiratory Syndrome Coronavirus 2: How to face this enemy. RGO, Rev Gaúch Odontol. 2020;68: e20200011. https://doi. org/10.1590/1981-863720200001120200034

3. Freitas ARR, Napimoga M, Donalisio MR. Assessing the severity of COVID-19. Epidemiol Serv Saude. 2020;29(2):e2020119. https://doi.org/10.5123/S1679-49742020000200008

4. Chan JF, Yuan S, Kok KH, To KK, Chu H, Yang J, et al. A familial cluster of pneumonia associated with the 2019 novel coronavirus indicating person-to-person transmission: a study of a family cluster. Lancet. 2020;395(10223):514-523. https:// doi.org/10.1016/S0140-6736(20)30154-9

5. Rothe C, Schunk M, Sothmann P, Bretzel G, Froeschl G, Wallrauch C, et al. Transmission of 2019-nCoV Infection from an Asymptomatic Contact in Germany. N Engl J Med. 2020;382(10):970-971. https://doi.org/10.1056/NEJMc2001468

6. Meng L, Hua F, Bian Z. Coronavirus Disease 2019 (COVID-19): emerging and future challenges for dental and oral medicine. J Dent Res. 2020;99(5):481-487. https://doi.org/10.1177/00 22034520914246

7. Coulthard P. Dentistry and coronavirus (COVID-19) - moral decision-making. Br Dent J. 2020;228(7):503-505. https:// doi.org/10.1038/s41415-020-1482-1

8. Abramovitz I, Palmon A, Levy D, Karabucak B, Kot-Limon N, Shay B, et al. Dental care during the coronavirus disease 2019 (COVID-19) outbreak: operatory considerations and clinical aspects. Quintessence Int. 2020;51(5):418-429. https://doi. org/10.3290/j.qi.a44392

9. Peng $X, X u X, L i$, Cheng L, Zhou X, Ren B. Transmission routes of 2019-nCoV and controls in dental practice. Int J Oral Sci. 2020;12(1):9. https://doi.org/10.1038/s41368-0200075-9
10. Li RW, Leung KW, Sun FC, Samaranayake LP. Severe acute respiratory syndrome (SARS) and the GDP. Part II: implications for GDPs. Br Dent J. 2004;197(3):130-134. https://doi.org/10. 1038/sj.bdj.4811522

11. Spagnuolo G, De Vito D, Rengo S, Tatullo M. COVID-19 Outbreak: an overview on Dentistry. Int J Environ Res Public Health. 2020;17(6):2094. https://doi.org/10.3390/ijerph17062094

12. Motta RH, Ramacciato JC, Groppo FC, Pacheco Ade B, de Mattos-Filho TR. Environmental contamination before, during, and after dental treatment. Am J Dent. 2005;18(5):340-344.

13. Ge ZY, Yang LM, Xia JJ, Fu XH, Zhang YZ. Possible aerosol transmission of COVID-19 and special precautions in dentistry. J Zhejiang Univ Sci B. 2020;21(5):361-368. https:// doi.org/10.1631/jzus.B2010010

14. Nejatidanesh F, Khosravi Z, Goroohi H, Badrian H, Savabi $O$. Risk of contamination of different areas of dentist's face during dental practices. Int J Prev Med. 2013;4(5):611-615.

15. Kobza J, Pastuszka JS, Bragoszewska E. Do exposures to aerosols pose a risk to dental professionals?. Occup Med (Lond). 2018;68(7):454-458. https://doi.org/10.1093/occmed/ kqy095

16. Zemouri C, de Soet H, Crielaard W, Laheij A. A scoping review on bio-aerosols in healthcare and the dental environment. PLoS One. 2017;12(5):e0178007. https://doi.org/10.1371/ journal.pone.0178007

17. Al-Amad SH, Awad MA, Edher FM, Shahramian K, Omran TA. The effect of rubber dam on atmospheric bacterial aerosols during restorative dentistry. J Infect Public Health. 2017;10(2):195-200. https://doi.org/10.1016/j.jiph.2016.04.014

18. Santos IR, Moreira AC, Costa MG, Castellucci e Barbosa MD. Effect of $0.12 \%$ chlorhexidine in reducing microorganisms found in aerosol used for dental prophylaxis of patients submitted to fixed orthodontic treatment. Dental Press J Orthod. 2014;19(3):95-101. https://doi.org/10.1590/21769451.19.3.095-101.oar

19. Paul B, Baiju RMP, Raseena NB, Godfrey PS, Shanimole PI. Effect of aloe vera as a preprocedural rinse in reducing aerosol contamination during ultrasonic scaling. J Indian Soc Periodontol. 2020;24(1):37-41. https://doi.org/10.4103/jisp. jisp_188_19

20. ADA Council on Scientific Affairs and ADA Council on Dental Practice Infection control recommendations for the dental office and the dental laboratory. J Am Dent Assoc. 1996;127(5):672-680. https://doi.org/10.14219/jada.archive.1996. 0280 